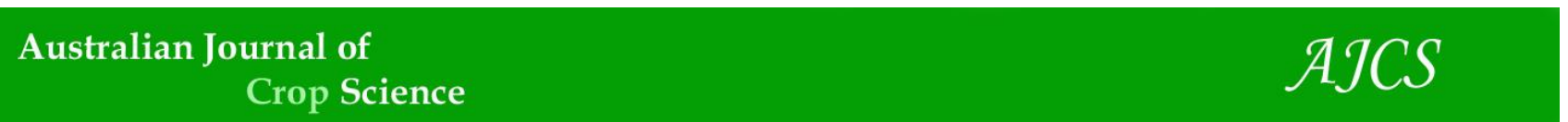

AJCS 13(11):1770-1776 (2019)

ISSN:1835-2707

doi: 10.21475/ajcs.19.13.11.p1549

\title{
Spraying deposits using different nozzles and application volumes for pest management of cotton at reproductive stage
}

\author{
Augusto Guerreiro Fontoura Costa ${ }^{1^{*}}$, Cleber Daniel de Goes Maciel ${ }^{2}$, Thiesli Rogoski ${ }^{3}$, Adelardo José Silva \\ Lira $^{1}$, Enelise Osco Helvig ${ }^{2}$
}

${ }^{1}$ Empresa Brasileira de Pesquisa Agropecuária - Embrapa Algodão. Rua Oswaldo Cruz, 1143. Campina Grande, PB, Brazil. Zip code: 58428-095

${ }^{2}$ Universidade do Centro-Oeste (Unicentro). R. Simeão Camargo de Varela Sá, 03. Guarapuava, PR, Brazil. Zip code: $85040-080$

${ }^{3}$ Instituto Matogrossense do Algodão. Rodovia BR163, km 726. Sorriso, MT, Brazil. Zip code: 78890-000

*Corresponding author: augusto.costa@embrapa.br

\begin{abstract}
With the growing need for greater operational capacity, information about the effect of application volume and spray nozzles on the quality of pesticide application are essential to obtain greater efficiency in pest management in cotton crops. This study aimed to assess the effect of the spraying volume and nozzles on the deposition of spray solution on cotton crops at the reproductive stage. The treatments of the first experiment correspond to the 55, 67, 140 and $194 \mathrm{~L} \mathrm{ha}^{-1}$ volumes obtained by variation of the displacement speed using the XR11004 flat fan nozzle. In the second assay the treatments corresponded to the applications of MGA9004 (hollow cone), XR11004 (flat fan), AIXR11004 (air induction flat fan) and CVIA04 (air induction hollow cone) nozzles with $120 \mathrm{~L} \mathrm{ha}^{-1}$. An artificial brilliant blue food dye (FD\&C 1) was used as a tracer $\left(2.5 \mathrm{~g} \mathrm{~L}^{-1}\right)$ to determine the deposited volumes on the leaves of the upper, middle and lower third of cotton plants. The results showed that increase in the application volume contributed to obtain the larger deposits in the upper third of the cotton crop during its reproductive phase, especially up to $140 \mathrm{~L}$ $\mathrm{ha}^{-1}$, but did not exhibit a significant increase of the deposition in the middle and lower thirds of the plants. The MGA9004, XR11004 and AIXR11004 nozzles provided the largest deposits in the three plant sectors. The flat fan nozzles resulted in greater uniformity of deposits in the upper and middle thirds of the plants.
\end{abstract}

Keywords: application volume, tip, spraying velocity, Gossypium hirsutum L.

Abbreviations: OM_organic matter; CEC_catio exchange capacity; V_base saturation; DAS_days after sowing.

Introduction

Cotton is widely used in the textile industry and has economic and social importance and is produced in over 75 countries. Despite the increase in productivity over the years, the occurrence of pests and diseases is one of the main challenges for the sustainability of cotton production systems due to the use of chemical control as the main management method (ICAC, 2015). In this context, the improper use of insecticides has contributed to environmental pollution, induced pest resurgence and resistance to these compounds (Luo et al., 2014), which may also increase production costs.

Ground boom sprayers are widely used in large crops because of their working capacity (Weicai et al., 2016), being normally predominant in relation to aerial applications. The western part of the state of Bahia is an important cotton producing region in Brazil. It has been reported that in Bahia only $35 \%$ of the production units calibrate the ground equipment in each application (Perina et al., 2016), indicating that the selection of the spray nozzle and adjustments to the application (spraying) volume, among other factors, might be contributing to less effective operations. Additionally, the tendency of reducing the application volume for gains in operational capacity may contribute to lower droplet deposition and consequently, makes the applications less effective, requiring greater knowledge about the effect of these operational conditions. In the state of Mato Grosso, which is the main cotton producing state in Brazil (CONAB, 2018), the average application volume used by producers has been decreased from 119 to $80 \mathrm{~L} \mathrm{ha}^{-1}$ between 2008 and 2016 (Carvalho et al., 2017).

In addition to the factors related to the sprayer, phytosanitary applications during the reproductive stages can make the arrival of biological targets even more difficult in certain plant sectors, especially for fungicides and insecticides. These stages the cotton plants are very close between rows and they have higer number of leaves (Cavalieri et al., 2015). It also depends to the pest, insect or pathogen development. At reproductive stages, the control of pest such as ramularia (Ramulara areola), the boll weevil (Anthomonus grandis), whitefly (Bemisia tabaci) and 
lepidoptera (Lepidoptera: Noctuidae) (Hardke et al., 2014; Belot and Vilela, 2017) can be more difficult.

Changings in application volume and nozzle type are among the actions commonly performed in filed conditions to improve the spray quality and pesticide application efficacy. Some studies have been carried out to better understand these factors in cotton crop, but they are scarce. Souza et al. (2007a) verified that flat fan air induction nozzle AD-IA 11003 promoted higher spray deposition within the cotton canopy than hollow cone JA-3 and double flat fan nozzles. Martin et al. (2010) found a higher deposition of novaluron insecticide for the application volume of $47 \mathrm{~L} \mathrm{ha}^{-1}$ compared to $19 \mathrm{~L} \mathrm{ha}^{-1}$, resulting in a higher efficiency in controlling Helicoverpa zea. Cavalieri et al. (2015) verified higher spray deposition in all plant parts with rotary atomizer disk at $20 \mathrm{~L} \mathrm{ha}^{-1}$ than flat fan nozzles without and with air induction (AXI and GA, respectively) at $120 \mathrm{~L} \mathrm{ha}^{-1}$.

Thus, new information related to the effect of the application volume and types of spray nozzles on the deposition of pesticides is of utmost importance in technical decisions regarding pest management in cotton crops. In this context, the purpose of this study is to evaluate the effect of application volumes and nozzles on the deposition of spray mix in the reproductive phase of cotton crops.

\section{Results and Discussion}

\section{Effect of spraying volume on deposition on cotton leaves}

Applications with $55 \mathrm{~L} \mathrm{ha}^{-1}$ did not indicate differences between depositions of spray mix on the leaves of the upper, middle and lower third of plants (Fig 1a), whereas over $80 \%$ of the samples, corresponded to spray deposits lower than $0.25 \mu \mathrm{L} \mathrm{cm}$, regardless of the position of sample.

For the application volumes of $67 \mathrm{~L} \mathrm{ha}^{-1}$ (Fig 1b) and especially, 140 and 194 Lha $^{-1}$ (Fig 1c and 1d, respectively), it was possible to verify greater differences between the deposits on the upper third of the plants in relation to the middle and lower third. For the three highest application volumes, approximately $80 \%$ of the leaves presented deposits higher than $0.25 \mu \mathrm{L} \mathrm{cm}$.

Thus, it can be observed that with an increase in the application volume there was a tendency to increase deposition on the upper part of the plants, while it did not necessarily improve the deposition on the middle and lower thirds, where the smaller deposits occurred. The highest retention of the spray mix in the upper sector of the plants, in relation to the middle and/or lower third was verified in other studies on cotton (Scramin et al., 2002; Sousa et al., 2007a; Cavalieri et al., 2015) and with soybean crops (Derkensen et al., 2008; Constantin et al., 2012; Cunha et al., 2016).

The deposit averages in the upper third were risen significantly with the increased volume applied up to $140 \mathrm{~L}$ $\mathrm{ha}^{-1}$. It was not possible to find differences between the 67 and $194 \mathrm{~L} \mathrm{ha}^{-1}$, by means of reliability intervals (Fig 2). The spray deposit decay was verified from 140 to $194 \mathrm{~L} \mathrm{ha}^{-1}$. It could be explained by some loss effect, as runoff from the leaves. For the middle and lower third of the plants there were no significant differences between treatments. In addition, for the lowest volume used ( $55 \mathrm{~L} \mathrm{ha}{ }^{-1}$ ), no differences were observed in the deposition of the application among the three plant sectors evaluated.

Considering conditions of this work, using flat fan nozzles with medium droplets, application volumes lower than 140 $\mathrm{L} \mathrm{h}^{-1}$ may be limiting to the efficacy of the products during the reproductive phase in the cotton. However, when there is the need to increase deposition in the middle and lower part of the plants, application volume might be increased as the only measure to be adopted, while it might not be effective. Souza et al. (2007a) reported that increase in application volume from 150 to $200 \mathrm{~L} \mathrm{ha}^{-1}$, using spray nozzles that produce coarse to extremely coarse droplets resulted in deposit increments in the middle third of cotton plants. In aerial applications with fine droplets produced by flat fan nozzles (CP-03), Martin et al. (2010) found a higher deposition of novaluron insecticide at the top of cotton plants for the application volume of $47 \mathrm{~L} \mathrm{ha}{ }^{-1}$ compared to $19 \mathrm{~L} \mathrm{ha}^{-1}$, resulting in a higher efficiency in controlling Helicoverpa zea.

Another point worth mentioning refers to greater lack of uniformity of deposits, which is easily verified by greater declivity of the curves from the upper part of the plants to applications equal or greater than $67 \mathrm{~L} \mathrm{ha}^{-1}$, accentuating from $140 \mathrm{~L} \mathrm{ha}^{-1}$ (Fig 1). Cavalieri et al. (2015), used tilted flat fan nozzles with air induction at $120 \mathrm{~L} \mathrm{ha}^{-1}$ and found an increase in droplet size variability and a reduction of deposition in cotton plants (top and bottom) due to the increase in displacement speed from 12 to 18 or $25 \mathrm{~km} / \mathrm{h}^{-1}$. Thus, considering that the change in displacement speed can interfere with the deposition (Peñazola et al., 2017), faster applications with lower volumes of spray mix may also have contributed to the smaller deposits observed in this study.

It is important to emphasize that the application volumes used in cotton production regions are increasingly lower (Costa and Sofiatti, 2015; Carvalho et al., 2017). In this context, the scenario is worrisome especially when there is need for the application deposition to reach the middle and lower sectors of the plants. Spraying with hydraulic nozzles should be performed in more careful manner, where a large number of technical factors involved.

In several situations, there will be the need to reduce droplet size and/or to adopt other technologies or measures that favor deposition along the plant. Martin et al. (2010), used an oil-based adjuvant in aerial application and reported higher droplet deposition and the control of Helicoverpa zea in low volume $\left(19 \mathrm{~L} \mathrm{ha}{ }^{-1}\right)$. Muhammad (2012) found higher deposition and lower drift with the assistance of air in the spray bar. Similarly, Cavalieri et al. (2015) and Mishra et al. (2015) also found higher deposition in different sectors of cotton plants with centrifugal energy rotating nozzles and electrostatic spray, respectively, compared to conventional applications.

\section{Effect of nozzle spray on deposition on cotton leaves}

The largest deposits occurred on the leaves of the upper third of the cotton plants for all spray nozzles (Fig 3 and 4), as observed in the treatments of the experiment with different application volumes (Fig 1 and 2).

Among the spray nozzles, the MGA9004 model (Fig 3a) showed a tendency for larger deposits on this plant sector with approximately $60 \%$ of the deposits on the targets, presenting values between 0.5 and $1.0 \mu \mathrm{L} \mathrm{cm}^{-2}$, and $20 \%$ with values greater than $1.0 \mu \mathrm{L} \mathrm{cm}$. Intermediate 

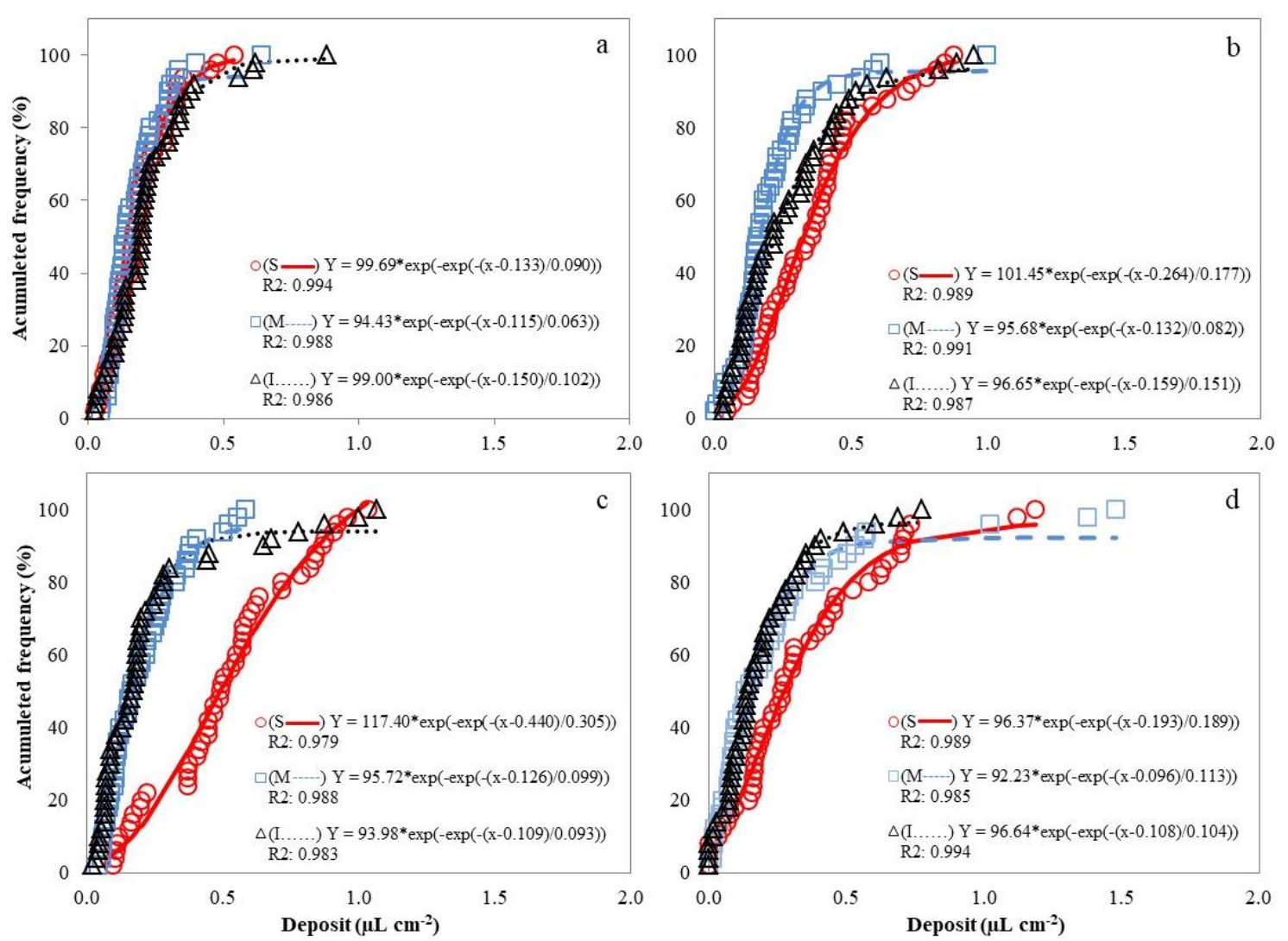

Fig 1. Accumulated frequencies represented by the percentage of leaves sampled in the upper (U), middle (M) and lower (L) thirds of cotton plants according to the deposited volumes per leaf area unit obtained with application volumes of 55 (a), 67 (b), 140 (c) and 194 (d) $\mathrm{Lha}^{-1}$.

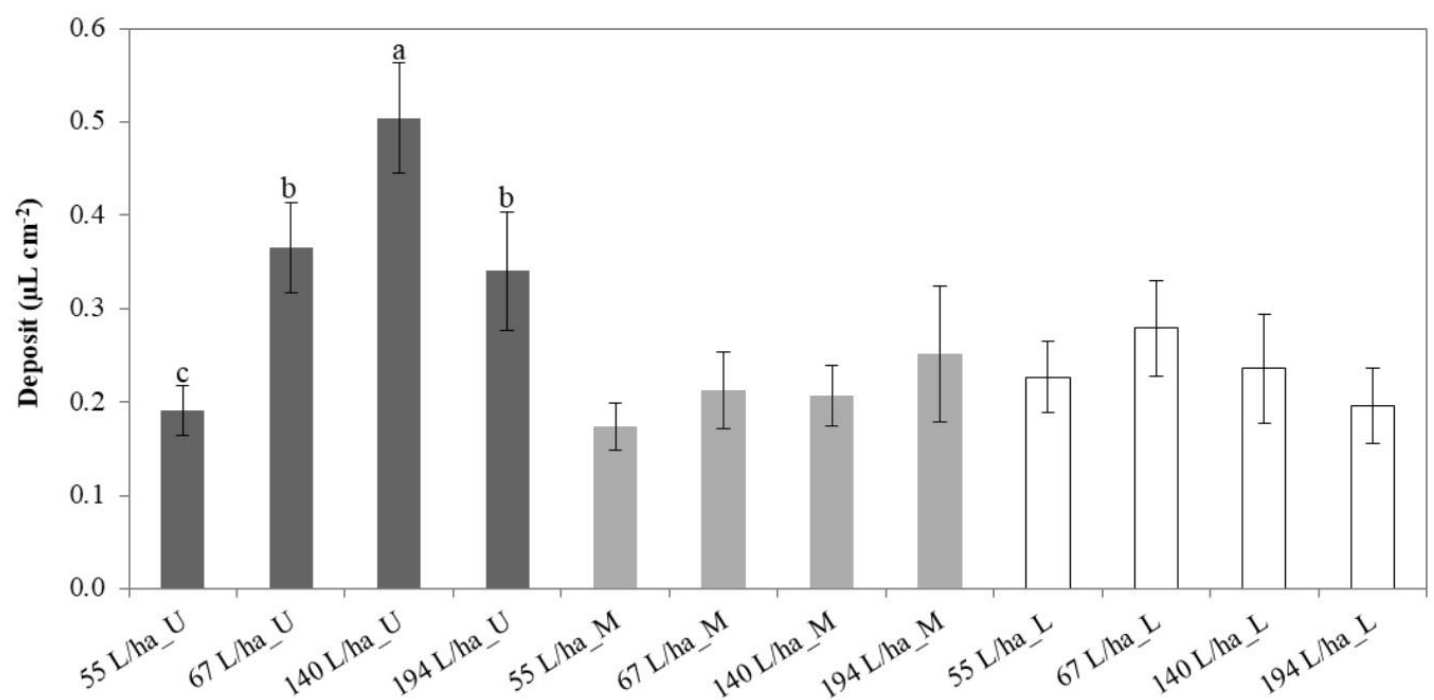

Fig 2. Deposit averages $\left(\mu \mathrm{L} \mathrm{cm}^{-2}\right)$ and the respective reliability intervals $(p \leq 0.05)$ in the upper $(U)$, middle (M) and lower (L) thirds of cotton plants obtained with the application volumes of $55,67,140$ and $194 \mathrm{~L} \mathrm{ha}^{-1}$. Means are not different by $\mathrm{t}$-test ( $\left.\mathrm{p} \leq 0.05\right)$ if followed by the same letter in each plant position. 

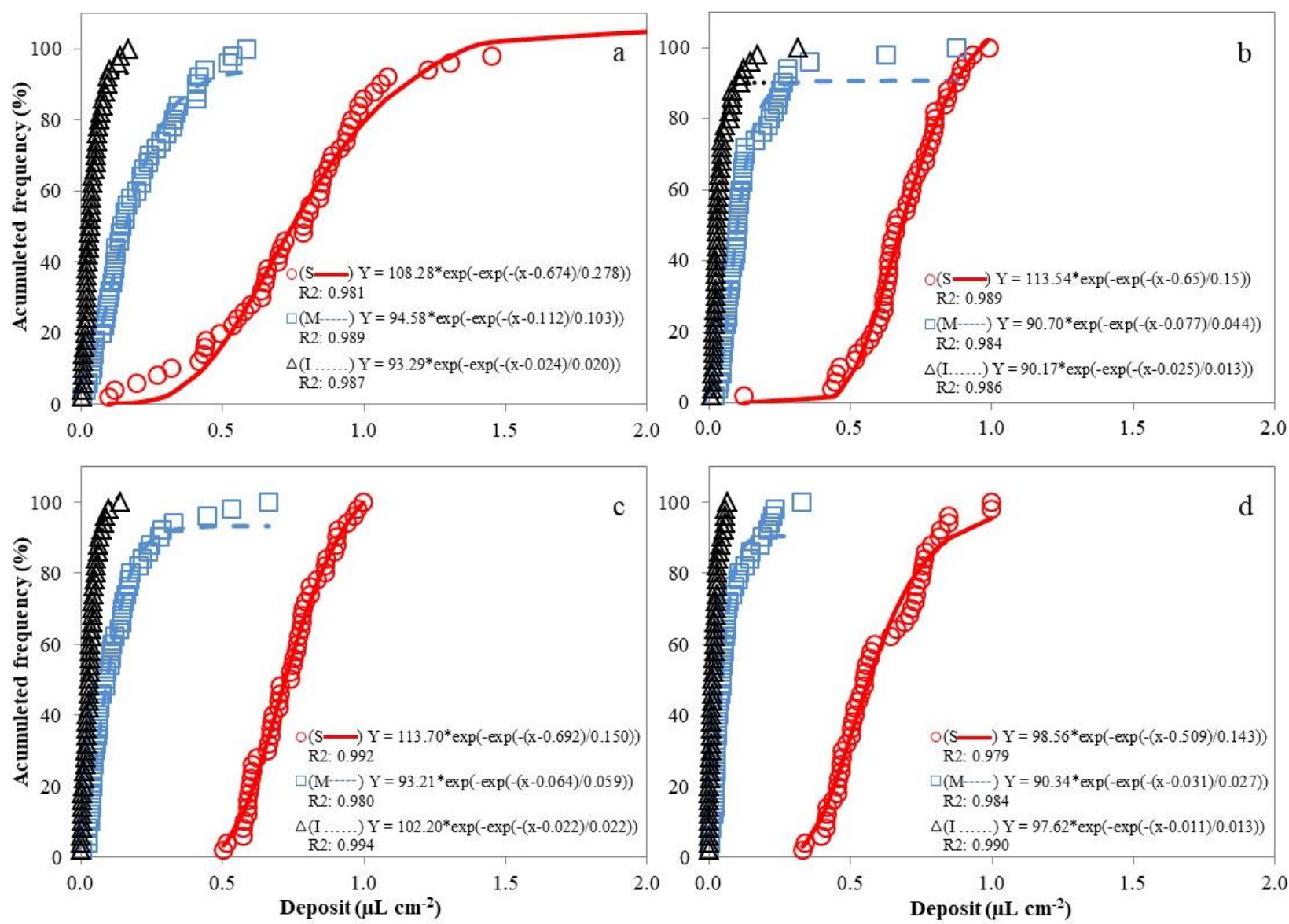

Fig 3. Accumulated frequencies represented by the percentage of leaves sampled in the upper (U), middle (M) and lower (L) thirds of cotton plants according to the deposited volumes per leaf area unit obtained with the MGA9004 (a), XR11004 (b), AIXR11004 (c) and CVIAO4 (d) spray nozzles.

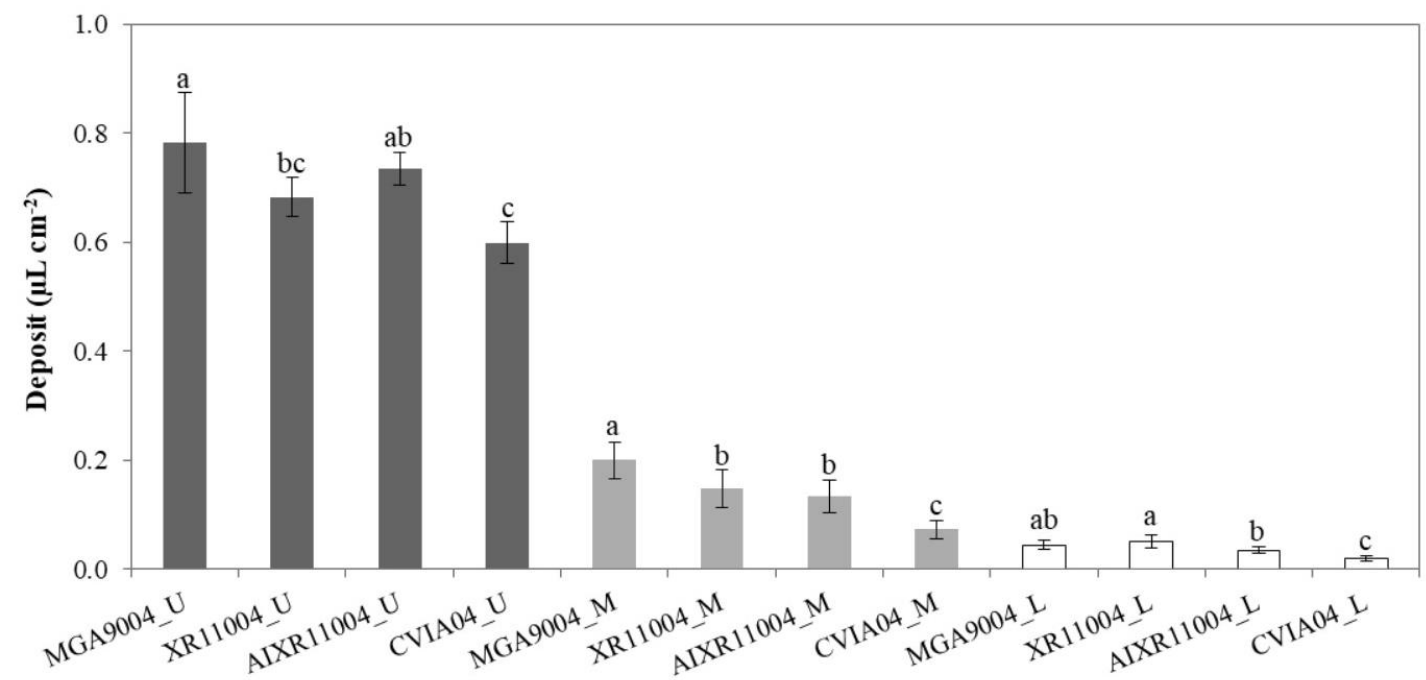

Fig 4. Deposit averages $\left(\mu \mathrm{L} \mathrm{cm}^{-2}\right)$ and the respective reliability intervals $(p \leq 0.05)$ in the upper $(U)$, middle (M) and lower (L) thirds of cotton plants obtained with the MGA9004, XR11004, AIXR11004 and CVIA04 spray nozzles. Means are not different by t-test $(p \leq 0.05)$ if followed by the same letter in each plant position. 
deposition values in the upper third of the plants were occurred in XR11004 and AIXR11004 nozzles (Fig 3b and $3 c$, respectively), whose deposits varied almost entirely between 0.5 and $1.0 \mu \mathrm{L} \mathrm{cm}^{-2}$. For the CVIA04 nozzle (Fig $3 d)$, approximately $40 \%$ of the samples showed deposits lower than $0.5 \mu \mathrm{L} \mathrm{cm}^{-2}$.

For the middle sector of cotton plants, the MGA9004 nozzle also resulted in a tendency of higher deposition values in comparison to the other treatments (Fig 3). Nozzles XR11004 and AIXR11004 presented intermediate deposition levels and the lowest values were obtained with the CVIA04 nozzle. However, the differences between treatments were lower in this plant sector, indicating the difficulty of arrival and capture of droplets. For the MGA9004 nozzle, only approximately $20 \%$ of the leaves evaluated had deposits greater than $0.25 \mu \mathrm{L} \mathrm{cm}^{-2}$. For the XR11004 and AIXR11004 nozzles, only approximately 10\% of the deposition was higher than this same value.

For the bottom sector of the plants, as observed in the study of different application volumes, most of the sampled leaves showed deposit values close to zero (Fig 3). This finding indicates the greater difficulty in reaching the lower portion of the plants at their reproductive stage, regardless of the type of spray nozzle and droplet size class applied.

Thus, a trend of greater deposits for the MGA9004 nozzle was found, followed by intermediate values obtained with the flat fan nozzles, especially for the upper and middle sectors of the cotton plants (Fig 3). However, in relation to deposit averages, no significant differences were found among the MGA9004, XR11004 and AIXR11004 nozzles. The values resulting from these treatments were higher than those obtained with the CVIAO4 nozzle in all sectors of the cotton plants (Fig 4). Thus, the smaller droplet sizes produced by the MGA9004 (fine), XR11004 (medium) and AIXR11004 (very coarse) nozzles compared to the CVIA04 nozzle (extremely coarse droplets), must have contributed to higher deposition in different plant sectors, in conform with similar findings obtained with the cotton (Cavalieri et al., 2015) and soybean crops (Cunha et al., 2016). As to the averages obtained in the second experiment, it is still worth mentioning that for the same spray nozzle, the deposits decreased significantly from the upper to the middle and lower sectors of the plants. However, despite the best results (highest deposits) were obtained with MGA, XR and AIXR nozzles in the three thirds of the plants, the smaller deposits verified in middle and lower sector will be enough for an effective pest control in these parts of the crop, depending on pesticide dose and the biological target. As to the dispersion of the data, it was possible to observe higher deposition variability for the MGA9004 hollow cone nozzle by means of the greater trend to the right of the curves of the accumulated frequencies, mainly for the upper and middle thirds of the plants (Fig 3). This greater dispersion of deposition data may be related to the amplitude of the droplet spectrum that varies depending on the spray nozzle model (Cunha et al., 2016). Costa et al. (2017) also found that the MGA9001 nozzle provided greater variability in the deposits compared to flat fan nozzles. In this sense, since the MGA9004 nozzle provides a finer droplet class among nozzles (Spraying Systems Co, 2014; Magnojet, 2017), the greater deposition variability may also have been caused due to losses occurring in the trajectory between the nozzle and the crop (Souza et al, 2007a). For the CVIA04 hollow cone nozzle, the greater variability of deposits occurred in the upper sector of the plants compared to the XR11004 and AIXR11004 nozzles (Fig 3). This larger dispersion of the deposition data for the cone nozzles may be related to the pattern of liquid distribution, which tends to show greater variation in the deposition of the spray along the boom with the overlapping of the jets when compared to flat fan nozzles. In this study, the greater uniformity of deposits on cotton was obtained by using XR11004 and AIXR11004 nozzles. It can be considered a benefit because dose variations can contribute to pesticide resistance by pest-insects in cotton and other crops (Helps et al., 2017). However, despite the higher deposition variability for the MGA9004, the fine droplets produced by this nozzle can improve the control of certain pests that present low mobility and simultaneously are hidden by certain plant structures. Then, the nozzle selection can be made based on spray deposition, but other facts as spray deposit (dose) variability, size droplet spectra and pest biological behavior must be considered in each situation.

\section{Materials and Methods}

\section{Plant materials, experimental design and conduction}

Two experiments were carried out in Sorriso (MT), Brazil, under field conditions, in an area located at coordinates $12^{\circ} 45^{\prime} 720^{\prime \prime} \mathrm{S}$ and $55^{\circ} 50^{\prime} 170^{\prime \prime} \mathrm{W}$, with an average altitude of $634 \mathrm{~m}$. The climate of the region is classified according to Köppen-Geiger as Aw, tropical with a dry season. The soil is classified as typical Dystrophic Red-Yellow Latosol (dRYL), with $63 \%$ of clay, $20 \%$ of sand and $17 \%$ of silt. The first test was focused on the application volumes and the second focused on the nozzles to assess the effects in the deposition of spray solution in foliar applications during the reproductive phase of cotton crops, conducted in June/2016 and May/2017, respectively.

During the two-year study, the cotton was sowed as a second crop in succession to a soybean crop, which is usually grown in the region where the studies were conducted (Takizawa, 2015). Before the beginning of the first crop season, the chemical characteristics of the soil presented for the layer depth of 0 to $20 \mathrm{~cm}$ were: $\mathrm{pH}$ in $\mathrm{CaCl}_{2}=5.0 ; \mathrm{Ca}^{+2}=2.7 \mathrm{cmol}_{\mathrm{c}} \mathrm{dm}^{-3} ; \mathrm{Mg}^{+2}=1.0 \mathrm{cmol}_{\mathrm{c}} \mathrm{dm}^{-3}$; $\mathrm{Al}^{+3}=0.0 \mathrm{cmol}_{\mathrm{c}} \mathrm{dm}^{-3} ; \mathrm{H}^{+}+\mathrm{Al}=5.0 \mathrm{cmol}_{\mathrm{c}} \mathrm{dm}^{-3} ; \mathrm{CEC}=8.9$ $\mathrm{cmol}_{\mathrm{c}} \mathrm{dm}^{-3} ; \mathrm{V}=43.4 \% ; \mathrm{P}=19.5 \mathrm{mg} \mathrm{dm}^{-3} ; \mathrm{K}^{+}=47.2 \mathrm{mg} \mathrm{dm}^{-3}$; $\mathrm{S}=13.9 \mathrm{mg} \mathrm{dm}^{-3}$ and $\mathrm{OM}=3.8 \%$. During the second year the characteristics were: $\mathrm{pH}$ in $\mathrm{CaCl}_{2}=5.6 ; \mathrm{Ca}^{+2}=4.0 \mathrm{cmol}_{\mathrm{c}}$ $\mathrm{dm}^{-3} ; \mathrm{Mg}^{+2}=1.5 \mathrm{cmol}_{\mathrm{c}} \mathrm{dm}^{-3} ; \mathrm{Al}^{+3}=0.0 \mathrm{cmol}_{\mathrm{c}} \mathrm{dm}^{-3} ; \mathrm{H}^{+}+\mathrm{Al}=$ $3.3 \mathrm{cmol}_{\mathrm{c}} \mathrm{dm}^{-3} ; \mathrm{CEC}=9.1 \mathrm{cmol}_{\mathrm{c}} \mathrm{dm}^{-3} ; \mathrm{V}=63.4 \% ; \mathrm{P}=21.0$ $\mathrm{mg} \mathrm{dm}{ }^{-3} ; \mathrm{K}^{+}=102 \mathrm{mg} \mathrm{dm}^{-3} ; \mathrm{S}=17.1 \mathrm{mg} \mathrm{dm}^{-3}$ and $\mathrm{OM}=$ $3.9 \%$. For each year, soil correction was performed before each soybean sowing with dolomitic limestone at rate equivalent to $2,000 \mathrm{~kg} \mathrm{ha}^{-1}$.

During the period between planting cotton and the application of the pesticides of the first experiment, the accumulated precipitation was $686 \mathrm{~mm}$ and the air temperature average was $26.5^{\circ} \mathrm{C}$. For the second test, they corresponded to $591 \mathrm{~mm}$ and $25.7^{\circ} \mathrm{C}$.

The cotton crop was planted on 02/14/16 and 02/09/17 using the IMA 5675 BT2RR and IMA 6501 BT2RF2 cultivars, respectively. For the first and second assays, 0.45 and $0.9 \mathrm{~m}$ spacing were used between rows, with populations of 215 and 89 thousand plants $\mathrm{ha}^{-1}$, respectively. In both experiments, fertilization was performed with $130 \mathrm{~kg} \mathrm{ha}^{-1}$ 
of $\mathrm{P}_{2} \mathrm{O}_{5}$ during sowing and $150 \mathrm{~kg} \mathrm{ha}^{-1}$ of $\mathrm{K}_{2} \mathrm{O}+80 \mathrm{~kg} \mathrm{ha}^{-1}$ of $\mathrm{N}$ at 30 days after planting. The phytosanitary management and the application of growth regulators were performed based on the recommendations for cotton crops (Belot, 2015).

\section{Treatments and conditions for the applications}

For the first experiment, the treatments consisted of 55 , 67, 140 and $194 \mathrm{~L} \mathrm{ha}^{-1}$ application volumes obtained from the following sprayer displacement speeds: 4, 6, 11 and 16 $\mathrm{km} \mathrm{h}^{-1}$. The spray nozzle used was the XR11004 flat fan with operating pressure of $100 \mathrm{kPa}$, which resulted in a spray class with medium-sized droplets (Spraying Systems Co, 2014).

In the second experiment, the treatments consisted of the spray nozzles MGA9004 (conventional hollow cone, $90^{\circ}$ jet pattern angle), XR11004 (extended range flat fan, $110^{\circ}$ jet pattern angle), AIXR11004 (air induction flat fan, $110^{\circ}$ jet pattern angle) and CVIA04 (air induction hollow cone, $100^{\circ}$ jet pattern angle), using an operating pressure of $300 \mathrm{kPa}$ and a displacement speed of $16 \mathrm{~km} \mathrm{ha}^{-1}$, which resulted in an application volume of $120 \mathrm{~L} \mathrm{ha}^{-1}$ for all the treatments. Under these pressure conditions, the droplets formed by each nozzle corresponded to fine, medium, coarse and very coarse spray classes, respectively. The flat fan and hollow cone nozzles used in this study are manufactured by Spraying Systems Co and Magno Jet Indústria Ltda, respectively (Spraying Systems Co, 2014; Magnojet, 2017). For the application in both experiments, we used a trailermounted sprayer with a 2,000 L tank and a pump with a capacity for $150 \mathrm{~L} \mathrm{~min}^{-1}$, equipped with an $18 \mathrm{~m}$ boom and hydraulic activation and 37 nozzles spaced at $0.50 \mathrm{~cm}$ and $0.5 \mathrm{~m}$ height relative to the apex of the cotton crop. Each treatment was applied in a continuous area with dimensions of $18 \mathrm{~m}$ wide and $50 \mathrm{~m}$ long, totaling $900 \mathrm{~m}^{2}$. A minimum distance of $30 \mathrm{~m}$ between the each application area was used to avoid spray drift interference between treatments. Treatments were applied at 108 and 104 days after planting (DAP) during the first and second experiments, respectively. In both situations, the cotton crop was in the R4 reproductive phenological stage, characterized from the first visible boll, in full bloom and closed canopy (Câmara and Chiavegato, 2001). During the first and second experiments, the plants presented an average of 1.0 and $1.7 \mathrm{~m}$ height and a leaf area index of 3.2 and 4.7, respectively. For the first experiment, the treatments were applied between 12:08 pm and 12:26 pm, in which the average wind speed, temperature and relative air humidity values obtained with a portable thermal hydro-anemometer corresponded to $0.8 \mathrm{~km} \mathrm{~h}^{-1} ; 35.9^{\circ} \mathrm{C}$ and $46.6 \%$, respectively. During the second experiment, the applications took place between 02:40 pm and 03:20 pm, presenting in average wind speed, temperature and relative humidity of $0.8 \mathrm{~km} \mathrm{~h}^{-1}, 36.3^{\circ} \mathrm{C}$ and $48.4 \%$, respectively.

\section{Evaluation of the deposition on cotton leaves}

In both experiments the spray solution consisted of water and an artificial brilliant blue food dye (FD\&C 1, Duas Rodas Industrial Ltda) as the tracer in a concentration of $2.5 \mathrm{~g} \mathrm{~L}^{-1}$. This tracer is considered to be suitable for studies evaluating deposition on field plant surfaces with the advantage of being stable while exposed to sunlight, not being absorbed by the leaves (Palladini et al., 2005; Souza et al., 2007a,b) and for not changing the viscosity of the spray mix (Alves et al., 2014).

After the applications, 50 leaves were randomly collected in the upper, middle and bottom positions of the cotton plants. In the first experiment, these parts corresponded respectively to 25,50 and $75 \mathrm{~cm}$ in relation to the soil due to the height of the crop, as well as 35,90 and $145 \mathrm{~cm}$ in the second experiment.

The samples were stored individually in plastic bags and transported to the laboratory to remove the deposit with $40 \mathrm{~mL}$ of deionized water. The wash solutions were stored in plastic containers kept under refrigeration and later analyzed in a visible UV spectrophotometer. For the quantification of the tracer in the samples, the optical density (absorbance) was measured at $630 \mathrm{~nm}$. In addition, the same procedure was used with the dilutions of the application solutions for the preparation of a calibration curve, whose results of the concentration readings $\left(\mathrm{mg} \mathrm{L}^{-1}\right)$ were used to determine the precise concentration of the tracer in the wash solution of the targets.

The concentration data of the samples was transformed into the deposited volume of spray solution per foliar area unit $\left(\mu \mathrm{L} \mathrm{cm}^{-2}\right)$ by using the estimated foliar area from the dimensions of each collected leaf (Monteiro et al., 2005).

\section{Statistical analysis}

The trial design was entirely randomized with 50 replications composed of leaves in the upper, middle and lower positions of the cotton plants. The unitary deposit data of the spray solution on the leaves were submitted to variance analysis and adjusted to the cumulative frequency (\%) to the Gompertz model. The deposition averages per plant sector of the treatments of each experiment were compared by the respective reliability compared by the respective reliability intervals and t-test at $5 \%$ probability $(p \leq 0.05)$.

\section{Conclusion}

Increased application volumes, especially up to $140 \mathrm{~L} \mathrm{ha}^{-1}$, contributed to obtain the largest deposits in the upper third of cotton crops in the reproductive stage, but without significant deposit increases in the middle and lower sectors of the plants. The MGA9004, XR11004 and AIXR11004 spray nozzles provided the largest deposits in the three sectors of cotton plants. The flat fan nozzles (XR11004 and AIXR11004) resulted in greater uniformity of deposits in the upper and middle thirds of the plants.

\section{Acknowledgements}

To the IMA-MT for the support granted for field experimentation.

\section{References}

Alves GS, Cunha JPAR, Palladini LA (2014) Seleção de traçadores para estudos de eficiência das aplicações de produtos fitossanitários. Planta Daninha. 32:861-870.

Belot JL (2015) Manual de boas práticas de manejo do algodoeiro em Mato Grosso. 1st edn. IMAmt, Cuiaba. $337 p$. 
Belot JL, Vilela P (2017) Compêndio de identificação: problemas agronômicos em algodoeiro e ferramentas de controle. 1st edn. IMAmt, Cuiaba. 304p.

Câmara GM, Chiavegato EJ (2001) O agronegócio das plantas oleaginosas: algodão, amendoim, girassol e mamona. 1st edn. ESALQ/PLV, Piracicaba. 204 p.

Carvalho FK, Chechetto RG, Mota AAB, Antuniassi U (2017) Characteristics and challenges on spray applications in Mato Grosso, Brazil. Outlooks Pest Manage. 28:4-6.

Cavalieri JD, Raetano CG, Madureira RP, Moreira LQ (2015) Spraying systems and traveling speed in the deposit and spectrum of droplets in cotton plant. Rev Eng Agríc. 35:1042-1052.

Companhia Nacional de Abastecimento - CONAB (2018) Algodão - série histórica. Available at: http://www.conab.gov.br/conteudos.php?a=1252. Accessed in: March 2018.

Constantin J, Santos G, Maciel CDG (2012) Característica da deposição e distribuição da calda de pulverização na cultura da soja em estádio fenológico $\mathrm{V}_{6}$. Eng Agríc. 32:530-541.

Costa AGF, Cruvinel PE, Peñazola EAG, Sugimoto PE (2017) Cobertura e densidade de gotas com diferentes pontas de pulverização para o manejo fitossanitário em culturas anuais. Paper presented at the 8th Simpósio Internacional de Tecnologia de Aplicação de Agrotóxicos, Fepaf, Campinas, 11-13 September 2017.

Costa AGF, Sofiatti V (2015) Tecnologia de aplicação de herbicidas na cultura do algodoeiro. In: Costa AGF, Sofiatti $V$ (ed). Manejo de plantas daninhas na cultura do algodoeiro. 1st edn. Embrapa, Brasília. 7.

Cunha JPAR, Marques RS, Alves GS (2016) Deposição da calda na cultura da soja em função de diferentes pressões de trabalho e pontas de pulverização. Ceres. 63:761-768.

Derkensen RC, Zhu H, Ozkan HE, Hammond RB, Dorrance $A E$, Spongberg AL (2008) Determining the influence of spray quality, nozzle type, spray volume, and air-assisted application strategies on deposition of pesticides in soybean canopy. Trans ASABE. 51:1529-1537.

Hardke JT, Jackson RE, Leonard BR (2014) Opportunities to manage fall armyworm (Lepidoptera: Noctuidae) on Bollgard $\|{ }^{\circ}$ cotton with reduced rates of insecticides. J Cotton Sci. 18:59-67.

Helps JC, Paveley ND, van den Bosch F (2017) Identifying circumstances under which high insecticide dose increases or decreases resistance selection. J Theor Biol. 428:153167.

International Cotton Advisory Committee - ICAC (2015) Measuring sustainability in cotton farming systems towards a guidance framework. Available at: https://www.icac.org/getattachment/Home-International-
Cotton-Advisory-Committee-ICAC/measuringsustainability-cotton-farming-full-english.pdf. Accessed in: March 2018.

Luo S, Naranjo SE, Wu K (2014) Biological control of cotton pests in China. Biol Control. 68:6-14.

Magnojet (2017) Bicos e acessórios. Magnojet, Ibaiti. 122 p.

Martin DE, Lopez JD, Lan Y, Fritz BK, Hoffmann C, Duke SE (2010) Novaluron as an ovicide for bollworm on cotton: deposition and efficacy of field-scale aerial applications. J Cotton Sci. 14:99-106.

Mishra PK, Singh M, Sharma A, Mahal KA (2015) Studies on effectiveness of electrostatic spraying for cotton crop. AMA Agr Mech Asia Af. 46:17-22.

Monteiro JEBA, Sentelhas PC, Chiavegato EJ, Guiselini C, Santiago AV, Prela A (2005) Estimação da área foliar do algodoeiro por meio de dimensões e massas das folhas. Bragantia. 64:15-24.

Muhammad Y (2012) Air assisted sleeve boom sprayer. AMA Agr Mech Asia Af. 43: 61-66.

Palladini LA, Raetano CG, Velini ED (2005) Choice of tracers for the evaluation of spray deposits. Sci Agríc. 62:440-445.

Peñaloza EAG, Cruvinel PE, Oliveira VA, Costa AGF (2017) A model approach to infer the quality in agricultural sprayers supported by knowledge bases and experimental measurements. Int J Semantic Comput. 11:279-292, 2017.

Perina F, Costa AGF, Wadt LGR, Chaim A (2016) Insecticides applications to control lepidopterans-pests in cotton and soybeans in wester Bahia region: an overview. Paper presented at the 6th World Cotton Research Conference, ICAC, Goiânia, 2-6 May 2016.

Scramin S, Chaim A, Pessoa MCPY, Ferracini VL, Pavan LA, Alvarenga N (2002) Avaliação de bicos de pulverização de agrotóxicos na cultura do algodão. Pesticidas: R Ecotoxicol Meio Amb. 12:43-50.

Souza RT, Castro RD, Palladini LA (2007a) Depósito de pulverização com diferentes padrões de gotas em aplicações na cultura do algodoeiro. Rev Eng Agríc. 27:7582.

Souza RT, Velini ED, Palladini LA (2007b) Aspectos metodológicos para análise de depósitos de pulverizações pela determinação dos depósitos pontuais. Planta Daninha. 25:195-202.

Spraying Systems Co (2014) Teejet - Catálogo 51A-PT. Spraying Systems Company, Wheaton. $160 \mathrm{p}$.

Takizawa E K (2015) Sistema de produção do algodão safrinha. In: Freire E C (ed). Algodão no cerrado do Brasil. 3rd edn. Positiva, Brasília. 18.

Weicai Q, Xinyu X, Cui L, Qingqing Z, Zhufeng X, Feilong C (2016) Optmization and test for spraying parameters of cotton defoliant sprayer. Int J Agric Biol Eng. 9:63-71. 